\title{
AGENCIFICATION IN THE EDUCATION SECTOR OF GEORGIA
}

\author{
Natia Gugunashvili, \\ Invited Lecturer, \\ Georgian National University SEU
}

\begin{abstract}
Agencification has been a recent trend on the agenda of public administration reforms in a number of countries. The concept of Agencification implies the rearrangement of the relation between the central government and the agencies as a result of delegation of tasks. Agencification process has been mostly driven by international organizations such as the OECD, IMF and the World Bank with the aim to introduce a "business-like" efficiency-oriented model in public sector in order to improve the performance and to raise the accountability. The following study explores the Agencification processes in the education sector of Georgia. Six agencies operating under the aegis of Ministry of Education and Science of Georgia have been examined. The empirical study shows that the relationship between the Ministry and the studied agencies goes beyond the classical model of principal-agent relationship and is based more on collaboration and cooperation principles. Shortcomings regarding the legal framework, old-fashioned performance measurement and performance management methods, constant reforms and structural changes put challenge to Agencification process. Furthermore, in the context of Georgia, there is no evidence that external actors - international organizations had an impact on the Agencification process in this very specific policy field. It was more an internal decision.
\end{abstract}

Keywords: Agencification, LEPLs, Education sector, principal-agent theory, legal framework.

\section{Introduction}

"One persistent theme in public administration is whether a government portfolio should be organized as an integrated ministry or as a dual organization composed of a ministerial department and one or several semidetached agencies." 1

"Since the 1980s there has been an explosion of interest in the agency model in many countries, driven largely by the pressures to restrain spending and make service to citizens more responsive." 2

"Agencification" has been high on the agenda of administrative policy makers for two decades and attracted considerable scholarly attention. ${ }^{3}$

The concept of Agencification implies the rearrangement of the relation between the central government and the agencies as a result of delegation of tasks. Agencification process has been mostly driven by international organizations such as the OECD, IMF and the World Bank with the aim to introduce a "business-like" efficiency-oriented model in public sector in order to improve the performance and to raise the accountability.

\footnotetext{
${ }^{1}$ J. Trondal, M. Egeberg, Agencification. ISL Working Paper No 4, 2013, p.2.

${ }^{2}$ SIGMA. Financial Management and Control of Public Agencies. SIGMA Paper No. 32. Paris: CCNM/SIGMA/PUMA 2001,4 p.8.

${ }^{3}$ J. Trondal, Agencification. Public Administration Review, 74(4), 2014, p.545.
} 
However, due to the ambiguity of the meaning and the lack of unified definition of agency idea, the term "Agency" took over different interpretations and was embedded in various organizational forms in different contexts.

"Agencification has been particularly virulent in the post-Soviet world."4 Georgia - a small, post-soviet country in the Caucasus is a good illustration for this. Just within this tiny country the number of officially recognized public law agencies rose to over 34000 as "the Rose revolution accelerated the pace of reform beginning in 2004 and by December 2005 the authorities had converted about 2700 individual schools into LEPLs." "The February 2004 Law on the Structure of the Georgian Government gave them a central role alongside ministries." ${ }^{\prime 6}$

In the period of 2004-2012 two waves of public administration reforms have been conducted in Georgian public sector. The first wave of reforms was directed towards establishing NPM model. However, one might assume that, as in other CEE countries, in Georgia as well an introduction of the NPM was a way to demonstrate the country's western orientation, rather than rational and consequent choice of the PA model. Introduction of the NPM in Georgia in the state of a developing country without strong state institutions, wellestablished professional civil service, well-developed free market, have led to the overall failure of the PA reform. ${ }^{7}$

Having mentioned the context of the introduction of the NPM model in Georgian public sector, there arises a question whether Agencificaton - an important part of the NPM doctrine, was a rational choice of the reform to make the government more efficient and responsive to citizens or as the NPM model in general, it can be also considered to be the mere demonstration that the country was following the reform trend?!

These thoughts lead to the main research questions of the paper, namely: To what extent has the agency (LEPL) reform been implemented in the case of Georgia and what has been the failure? To what extent are the agencies in Georgia autonomous?

\section{Theoretical Framework}

\subsection{The Agency Idea}

The creation of the Agency model dates back to the global economic upheavals of the 1970s when the governments faced three large problems:

1. Financial: As the cost of continuing to run welfare states has climbed, the ability to tax seems to have diminished. These circumstances have created tremendous pressures to restrain the rate of growth of public expenditures - to economize;

2. An apparent decline in citizen trust in government institutions;

3. Rising citizen expectations with respect to the standards of public services.

\footnotetext{
${ }^{4}$ B. Lehmbruch, "It takes two to quango: post-Soviet fiscal relations, political entrepreneurship and agencification from below". ISS Working Paper Series/General Series, 538(538), 2012, p. 5.

${ }^{5}$ S. M. George, A. Billmeier, S. Ding, K. Fedorov, I. Yackovlev \& J. Zeuner, "Legal Entities of Public Law in Georgia: Accountability and Reform". Georgia: Selected Issues 2006, p. 42.

${ }^{6}$ B. Lehmbruch \& L. Sanikidze, "Soviet legacies, new public management and bureaucratic entrepreneurship in the Georgian protection police. Agencifying the police?" Europe-Asia Studies, 66(1) 2014, p.92.

${ }^{7}$ N. Dolidze, "Public administration reforms in Georgia: establishing administrative model for state organizations." Caucasus Social Science Review (CSSR), 2, 2015, pp. 15-16.
} 
Those problems together led directly to the proposition, articulated most loudly in the U.S.A. but echoed in many other countries, that governments must "do more with less". "This is where agencies come in. It's believed that agencies can help governments work better, yet more economically.""

Scholars outline organizational, functional, contingency and institutional (myth) approaches to explain Agencification. Organizational/institutional approach implies that agencies come about through power struggles and compromises conditioned by pre-existing organizational structures. According to the argument of functionalist approach, Agencification is a response to collective action problems, namely - agencies contribute to the reduction of political transaction costs, by providing solutions to collective-action problems that prevent efficient political exchange. Contingency approach suggests that decisions to create agencies have been motivated by needs to respond to particular circumstances of the moment. Finally, according to the institutional (myth) approach, the creation of agencies can also be seen as a trend in public policy and as a fashionable idea within the realms of public management. ${ }^{9}$

A number of academics have attempted to produce short definition of agencies:

"By an "agency", we mean an administrative body that is formally and organizationally separated from a ministerial, or cabinet-level, department and that carries out public tasks at a national level on a permanent basis, is staffed by public servants, is financed mainly by the state budget, and is subject to public legal procedures" 10

Attempting to define the agency idea, one can't avoid the difficulties the scholars face to deliver a definition that would fit every case.

"As even a cursory review of international experience reveals, the term public agency, when used by a national government, really carries whatever meaning that government wishes to give to it." 11

Pollit et al explain the reasons that complicate the uniform definition of agencies:

1. "Variation in public law between countries: the available legal boxes into which different kinds of public bodies may be placed vary widely;

2. Language itself: There are subtle shades of difference between the terms used in different languages. Important meanings may be lost in translation and new ones may unintentionally slip in;

3. Variation in political system: Two entities with broadly similar legal statues and formal powers may in fact operate in startlingly different ways because they are embedded in different kinds of political systems." 12

\subsection{Principal-Agent Theory}

Agencification is often discussed and presented within the framework of principal-agent theory.

\footnotetext{
${ }^{8}$ C. Pollit, K. Bathgate, J. Caulfield et al. “Agency Fever: Analysis of an International Policy Fashion”, Journal of Comparative Policy Analysis: Research and Practice, 3, 2001, pp.276-277.

${ }_{9}^{9}$ J. Trondal, M. Egeberg, Agencification. ISL Working Paper No 4, 2013, p.5.

${ }^{10}$ M. Egeberg \& J. Trondal, "Political leadership and bureaucratic autonomy: Effects of agencification". Governance, 22(4) 2009, p.674.

${ }^{11}$ SIGMA. Financial Management and Control of Public Agencies. SIGMA Paper No. 32. Paris: CCNM/SIGMA/PUMA 2001,4, p.14.

${ }^{12}$ C. Pollit, K. Bathgate, J. Caulfield et al. “Agency Fever: Analysis of an International Policy Fashion”, Journal of Comparative Policy Analysis: Research and Practice, 3 2001, pp. 273-274.
} 
The principal-agent theory in the field of political science gained popularity in the 1970s, as political scientists were developing a more diverse array of scenarios for the delegation of power than were associated with the paradigm of economists. The main tenets of the paradigm in political science are the same as those in the economic version: "Principles delegate to agents the authority to carry out their political preferences. However, the goals of principles and agents, may conflict and because of asymmetries of information, principles cannot be sure that agents are carrying out their will. Political principles also face problems of adverse selection, moral hazard and agent opportunism. So, principles contrive incentives to align agent interests with their own and undertake monitoring of agent behaviour, activities that create agency costs." 13

However, details are quite different. Political scientists assume multiple actors and consider a more diverse set of scenarios for delegating power beyond those inherited from the economics paradigm that call for a very different agency contract. For example, principals may delegate to agents to enhance the credibility of their commitments, to avoid blame for unpopular policies, etc. These scenarios imply a completely different agency contract. Principles that seek credibility from their agents select agents operating at arm's length, with different policy preferences, and grant considerable discretion and autonomy to them while still seeking to insure accountability. ${ }^{14}$

Abovementioned agency idea and the process of Agencification implies also different agency contract. As already mentioned, "justification for this kind of agency contract and public sector reform generally was to increase efficiency and effectiveness, enhance the autonomy of managers, place services closer to citizens, reduce political meddling and enable ministries to concentrate on the big policy issues." 15

This kind of agency contract also implies a set of different actors - internal and external actors willing to implement the reform and veto-players. The existence and the role of external actors is especially significant in the context of the countries in transition that strive to establish democratic institutions. Foreign policy orientation and priorities associated with the membership of the international organizations have also an important impact on public administration reforms in the country.

Herewith, the main hypothesis of the paper is formulated:

H: "Agencification experience in Georgia implies different agency contract with a variety of actors, interests and goes beyond the classical economic model of principal-agent relationship."

\section{Research Design and Methodology}

In order to study the research question of the paper and to figure out to what extent the agency reform has been implemented in a specific context of the public sector, indicators will be defined based on the abovementioned definitions of the agency idea and the corresponding theoretical framework. The author will analyse the extent of the implementation of the reform along those indicators and will provide some insights on the question whether agency as an administrative model is functioning in the context of Georgia.

Based on the abovementioned definitions of the agency idea, three central elements have to be distinguished that make up the core of the 'agency' model:

\footnotetext{
${ }^{13}$ S. P. Shapiro, “Agency theory.” Annu. Rev. Sociol., 31 2005, p. 271.

${ }^{14}$ Ibid.

${ }^{15}$ B. Verschuere \& D. Vancoppenolle "Policy-making in an era of agencification: An exploration of task divisions between politicians, core departments and public agencies.” Policy and Society, 31(3) 2012, p.249.
} 
1. Structural separation/disaggregation and the creation of 'task specific' organizations

2. Managerial Autonomy in making decisions regarding personnel and financial management

3. Managerial Accountability over personnel, finance and other management matters

First important feature of agency model is structural separation that implies the legal autonomy and involves splitting up Ministries into core central body and several agencies carrying out specific tasks. In order to study the degree of separation, legal framework will be analysed.

\begin{tabular}{|l|l|}
\hline Legal Framework & Degree of Separation/Legal Autonomy \\
\hline Agencies are said to be separate but within the parent Ministry & Low \\
\hline Agencies have their own legal personality & High \\
\hline
\end{tabular}

Second important feature of the agency model implies the degree of managerial autonomy.

"The concept of autonomy refers to a capacity to act independently from the control of other actors"16 and is defined "as the level of decision-making competency (discretion) of an organization." 17 The concept of autonomy refers to different kinds of autonomy, such as legal autonomy (already mentioned above) managerial autonomy, policy autonomy as well as financial autonomy. ${ }^{18}$

Managerial autonomy constitutes the core of the NPM ideal-type agency model and implies that an agency "has the right to take decisions about managerial matters (concerning personnel and financial management) independently, without needing approval of the parent department, or ministries." 19

The main argument for more managerial autonomy and the idea of 'letting the managers manage' free from the bureaucratic and political constraints is that it increases agency efficiency, effectiveness and accountability by placing direct responsibility on the agency itself. ${ }^{20}$

In order to provide a comprehensive picture about the autonomy of the agencies, policy autonomy of the agencies will be also examined. One should differ between policy formulation and policy implementation autonomy. Policy formulation autonomy implies discretion and leeway in defining and formulating policy goals, precise objectives, task prioritization etc. "Policy implementation autonomy refers to the discretionary authority of agencies to decide on certain aspects of the implementation of policies, without needing approval of the parent department or minister." 21

Financial autonomy implies the extent to which the agency is financially independent - whether it has its own budget or is funded through the state budget.

To study the degree of autonomy following criteria will be analysed:

\footnotetext{
${ }^{16}$ T. Bach, B. Niklasson \& M. Painter, "The role of agencies in policy-making.” Policy and Society, 31(3) 2012, p.185.

${ }^{17}$ K, Verhoest, S. Van Thiel, G. Bouckaert, P. Laegreid, \& S. Van Thiel, (Eds) Government agencies: Practices and lessons from 30 countries. London: Palgrave Macmillan. 2012, p.7.

${ }^{18}$ Ibid p. 420 .

${ }^{19}$ Ibid p.8.

${ }^{20}$ Ibid pp.421-422.

${ }^{21}$ Ibid p.8.
} 


\begin{tabular}{|l|l|}
\hline Who decides on the head of the agency? & Degree of Autonomy \\
\hline Prime-Minister & Medium autonomy \\
\hline Minister & Low autonomy \\
\hline Parliament & High autonomy \\
\hline
\end{tabular}

\begin{tabular}{|l|l|}
\hline Budget & Degree of Autonomy \\
\hline Own Budget & High Autonomy \\
\hline $\begin{array}{l}\text { Dependent on the state budget but the ability to have its } \\
\text { own revenues }\end{array}$ & Medium Autonomy \\
\hline Fully dependent on the state budget & Low Autonomy \\
\hline
\end{tabular}

\begin{tabular}{|l|l|}
\hline Staff & Degree of Autonomy \\
\hline Appointment/Recruitment by the Agency & High Autonomy \\
\hline Appointment/Recruitment by the Ministry & Low Autonomy \\
\hline
\end{tabular}

Regarding the analysis of the agency staff, focus will be placed on the agency personnel only at the later stage, after the agency is separated from the ministry - not at the beginning, when the agency is still a part of the ministry.

\begin{tabular}{|l|l|}
\hline Policy Formulation & Degree of Autonomy \\
\hline $\begin{array}{l}\text { Agencies can define and formulate precise policy objectives, target } \\
\text { groups, instrument choice or task prioritization independently }\end{array}$ & High Autonomy \\
\hline $\begin{array}{l}\text { Agencies can participate in consultations with the parent Ministry } \\
\text { and contribute to the definition and formulation of precise policy } \\
\text { objectives, target groups, instrument choice or task prioritization }\end{array}$ & Medium Autonomy \\
\hline $\begin{array}{l}\text { Agencies get the precise policy objectives, target groups, instruments } \\
\text { choice or task prioritization dictated by the parent ministry }\end{array}$ & Low Autonomy \\
\hline
\end{tabular}




\begin{tabular}{|l|l|}
\hline Policy Implementation & Degree of Autonomy \\
\hline $\begin{array}{l}\text { Agencies can decide on certain aspects of the implementation without } \\
\text { the approval of parent Ministry }\end{array}$ & High Autonomy \\
\hline $\begin{array}{l}\text { Agencies can decide on certain aspects of the implementation only } \\
\text { with the approval of parent Ministry }\end{array}$ & Low Autonomy \\
\hline
\end{tabular}

The third aspect of the agency model is the idea of steering and control system. The agencies are semiautonomous entities and the principles will usually use different forms for control and steering to constrain their autonomy. In most countries, parent ministries are the main principles that supervise the performance of the agencies, but in a small number of countries there are other principals involved in the steering and control of agencies besides parent ministries, for example, parliament and other line ministries, or central ministries. ${ }^{22}$ Steering and control system may entail setting targets for and reporting on the activities of an agency and may involve performance management, cost-cutting and budgetary discipline. However, Steering and control can also take the form of various rules, regulations and standards issued by governmental institutions or international organizations such as the EU or the WTO. ${ }^{23}$

In order to analyse third aspect of the agency model two dimensions will be studied: 1 . Existence of performance management measures and procedures 2. (International) Regulations and standards imposed on the agency.

In order to study the extent of the implementation of agency reform, author focuses on the education sector for two reasons: 1. Education is of utmost importance to build a contemporary, fair and competitive state. High Education plays especially crucial role in the development of society in post-soviet states and has an impact on the economic growth of the country. Education sector constitutes a crucial policy field in Georgia. The country has undergone a set of reforms during the last decades. Government officials constantly make statements about the importance of this policy sector and underline that improving and reforming education sector belongs to the main priorities of the state policy.

2. There is no systematic study of the agencification process in the field of education in Georgia so far. The author intends to fill this gap with the following study.

Case study research as a core method of study has been applied. An in-depth analysis of a set of typical cases for the agencies in the education sector has been conducted. "The typical case study focuses on a case that exemplifies a stable, cross-case relationship. By construction, the typical case may also be considered a representative case, according to the terms of what-ever cross-case model is employed." 24

Case study research implies the study of a variety of data and evidence. In the following study, documentation and interviews are the main sources for the data. Following methods have been applied: 1. Content analysis method to study and to analyse the Statutes, establishing documents of the agencies and the law that describes the Agencification process in Georgia and 2. Interview method.

\footnotetext{
${ }^{22}$ Ibid pp.425-426.

${ }^{23}$ M. Asensio, "Has Agencification succeeded or failed in public sector reform? The case of Portugal." 2011, p.6.

${ }^{24}$ J. Seawright \& J. Gerring, "Case selection techniques in case study research: A menu of qualitative and quantitative options." Political research quarterly, 61(2) 2008, p.299.
} 
In order to study the Agencification process in the education sector typical cases operating under the aegis of the Ministry of Education and Science of Georgia have been chosen: LEPL Shota Rustaveli National Science Foundation of Georgia, LEPL Education Management Information System, LEPL International Education Centre, LEPL National Centre for Education Quality Enhancement, LEPL National Examinations and Assessment Centre, LEPL Office of Resource Officers of Educational Institutions, LEPL National Centre For Teacher Professional Development, LEPL Educational and Scientific Infrastructure Development Agency.

Interviews with the directors/deputy-directors of six agencies - LEPLs had been conducted. Interviews couldn't be conducted in LEPL National Centre for Education Quality Enhancement and LEPL National Center for Teacher Professional Development.

\section{Discussion of findings}

The conducted study showed that the agencies in the education sector execute a wide range of specific tasks. They supplement and contribute to the functioning of the System of Ministry of Education and Science of Georgia. The LEPLs are task specific organizations with their particular area of action.

Based on the results of the empirical study, following conclusions can be drawn:

Agencies in Georgia, so called LEPLs, have a high degree of legal autonomy. They possess their own legal personality. Legal aspects of their functioning are regulated by the Law of Georgia on Legal Entities under Public Law and different normative and legal acts of Georgia dependent on their specific mission and tasks that they execute.

In 5 cases, the decision on the head of the agency is made by the Minister. In the case of the LEPL Educational and Scientific Infrastructure Development Agency, the head is appointed by the Prime-Minister due to the scale and importance of activities implemented by the agency and the size of the budget.

Financial autonomy of the agencies is assessed as medium. In all 6 cases, agencies are financed by the state budget, but the LEPLs are also entitled to receive independent revenues based on their expertise. Regarding state budget, after the approval of the budget plan by the government and the Ministry, the agencies can dispose allocated budget independently and in some cases they are also entitled to make some minor modifications.

The agencies have high autonomy in making decisions regarding personnel management. They are fully independent in terms of recruitment of staff. However, modifications regarding the number or structure of personnel require the approval of the Ministry.

General policy directions and priorities at the conceptual level are defined by the government and the Ministry of Education and Science of Georgia. The LEPLs are usually the administrators and implementers of these decisions. However, there is a possibility for the agencies to engage in political consultations with the Ministry and based on their expertise contribute to the policy formulation. In the four examined cases the degree of autonomy in terms of policy formulation has been assessed as medium. Different outcomes in two cases (LEPL National Assessment and Examinations Center - low and LEPL International Education Center - high) are due to the specific nature of the mission and tasks executed by the agencies.

The Ministry of Education and Science of Georgia is the main principal the agencies are accountable to. However, regarding financial aspects Ministry of Finance and State Audit Office of Georgia are also involved in the control and steering process. Based on the 112-th order of the Ministry of Finance, the agencies are obliged to submit standardized performance reports quarterly. The Ministry of Education and Science of 
Georgia is also entitled to request the additional information and documentation from the LEPL for the purpose of control and steering.

There are no international regulations issued by the international organizations that are imposed on the agencies. However, the LEPLs are usually under the indirect influence of all international agreements and conventions signed by the government of Georgia.

\section{Conclusion}

What kind of agency contract does the Agencification experience in Georgia imply on the example of the education sector?!

A wide range of specific tasks executed by various LEPLs makes this agency contract so different. LEPLs are there in order to supplement and to assist the Ministry in fulfilling its policy.

Empirical examples show that the relationship between the Ministry and the agencies are often based on collaboration and cooperation principles. Principal - Ministry of Education and Science delegates its authority because it needs more resources to execute a wide range of tasks. Without agencies the Ministry wouldn't be able to implement this policy. So, the principal and the agents assist and supplement each other. The LEPLs examined in the study build and contribute to the system and functioning of the Ministry.

This agency contract implies multiple actors. In addition to the Ministry of Education and Science which is the main principal in this relationship, Ministry of Finance might be also considered as a principal that the agencies are financially accountable to.

Regarding the actors willing to implement the reform, there is no evidence that external actors - international organizations had an impact on the Agencification process in this very specific policy field. It was more an internal decision.

Analyzing the failures of the Agencification process, one should definitely underline the shortcomings regarding the legal framework. The main law regulating the Agencification process in Georgia - The Law of Georgia on Legal Entities under Public Las was amended in 1999. The law has been criticized for its lacks of concreteness.

Performance management and measurement methods described in the study are considered to be old-fashioned and obsolete.

Legal status of employees constitutes another challenge. There was a long debate about whether the employees of the agencies should also be considered and treated as public servants. According to the new regulations, they will also have a legal status of public servant.

Constant reforms and structural changes put another challenge to the Agencification. E. g. in order to make the bureaucracy more effective, a number of Ministries have been merged in 2018. This had it as a result that the agencies operating under the aegis of the Ministry of Culture, Sport and Youth at the moment of conducting the empirical study belonged to the system of the Ministry of Education, Science, Culture and Sport. Such developments might be also considered as a challenge. 
Finally, one should note that the study is subject to some limitations. Education sector has its specificity that limits the generalization of the outcomes. So, depending on the policy field, the relationship between the Ministry and Agencies also varies. Each Ministry has its specificity and work culture with agencies. 


\section{Bibliography:}

1. Maria Asensio, "Has Agencification succeeded or failed in public sector reform? The case of Portugal."2011. Available at: https://soc.kuleuven.be/io/egpa/org/2011Roem/papers/ Paper\% 20Maria\% 20Asensio.pdf [Last seen 01.06.2019];

2. Tobias Bach, Birgitta Niklasson \& Martin Painter, "The role of agencies in policy-making." Policy and Society, 31(3). 2012;

3. Nino Dolidze, "Public administration reforms in Georgia: establishing administrative model for state organizations." Caucasus Social Science Review (CSSR), 2. 2015;

4. Morten Egeberg, \& Jarle Trondal, "Political leadership and bureaucratic autonomy: Effects of agencification." Governance, 22(4). 2009;

5. Susan M. George, Andreas Billmeier, Shuang Ding, Konstantin Fedorov, Irene Yackovlev, \& Joerg Zeuner, "Legal Entities of Public Law in Georgia: Accountability and Reform." Georgia: Selected Issues. 2006, 41-50. IMF, Washington, DC;

6. Barbara Lehmbruch, "It takes two to quango: post-Soviet fiscal relations, political entrepreneurship and agencification from below." ISS Working Paper Series/General Series. 538(538), 2012;

7. Barbara Lehmbruch \& Lia Sanikidze, "Soviet legacies, new public management and bureaucratic entrepreneurship in the Georgian protection police. Agencifying the police?" Europe-Asia Studies, 66(1), 2014;

8. Christopher Pollit, Karen Bathgate, Janice Caulfield, Amanda Smullen, Colin Talbot, "Agency Fever: Analysis of an International Policy Fashion", Journal of Comparative Policy Analysis: Research and Practice, 3, 2001;

9. Jason Seawright \& John Gerring, "Case selection techniques in case study research: A menu of qualitative and quantitative options." Political research quarterly, 61(2), 2008;

10. Susan P. Shapiro, "Agency theory." Annu. Rev. Sociol., 31, 2005;

11. SIGMA. Financial Management and Control of Public Agencies. SIGMA Paper No. 32. Paris: CCNM/SIGMA/PUMA (2001)4, April (available at www.oecd.org/puma/sigmaweb);

12. Jarle Trondal, Morten Egeberg, Agencification. ISL Working Paper No 4, 2013;

13. Jarle Trondal, “Agencification." Public Administration Review, 74(4), 2014;

14. Bram Verschuere \& Diederik Vancoppenolle, "Policy-making in an era of agencification: An exploration of task divisions between politicians, core departments and public agencies." Policy and Society, 31(3), 2012;

15. Koen Verhoest, Sandra Van Thiel, Geert Bouckaert, Per Lægreid \& Sandra Van Thiel (Eds.) Government agencies: Practices and lessons from 30 countries. London: Palgrave Macmillan, 2012;

16. Law of Georgia on legal entities under Public Law, 1999;

17. Order of Minister of Education and Science of Georgia N 229/N on the establishment and approval of the statute for the LEPL Education Management Information System;

18. Order of Minister of Education and Science of Georgia N 74/N on the approval of the statute for the LEPL Office of Resource Officers of educational Institutions;

19. Order of Minister of Education and Science of Georgia N 62 on the establishment and approval of the statute for the LEPL Shota Rustaveli National Science Foundation of Georgia;

20. Order of Minister of Education and Science of Georgia N 225/N on the reorganization and approval of the statute for the LEPL Education and Infrastructure development agency;

21. Order of Minister of Education and Science of Georgia N 180/N on the approval of the Statute for the LEPL International Education Center. 